\title{
Dietary inulin intake and age can significantly affect intestinal absorption of calcium and magnesium in rats: a stable isotope approach
}

\author{
Charles Coudray*, Mathieu Rambeau, Christine Feillet-Coudray, \\ Jean Claude Tressol, Christian Demigne, Elyett Gueux, Andrzej Mazur and \\ Yves Rayssiguier
}

Address: Centre de Recherche en Nutrition Humaine d'Auvergne, Unité Maladies Métaboliques et Micro-nutriments, INRA, Theix, 63122 St-GenèsChampanelle, France

Email: Charles Coudray* - coudray@ensam.inra.fr; Mathieu Rambeau - mrambeau@clermont.inra.fr; Christine FeilletCoudray - cfeillet@ensam.inra.fr; Jean Claude Tressol - tressol@clermont.inra.fr; Christian Demigne - demigne@clermont.inra.fr; Elyett Gueux - gueux@clermont.inra.fr; Andrzej Mazur - mazur@clermont.inra.fr; Yves Rayssiguier - yrayssig@clermont.inra.fr

* Corresponding author

Published: 27 October 2005

Nutrition Journal 2005, 4:29 doi:10.1/86/1475-289/-4-29

This article is available from: http://www.nutritionj.com/content/4/I/29

(C) 2005 Coudray et al; licensee BioMed Central Ltd.

This is an Open Access article distributed under the terms of the Creative Commons Attribution License (http://creativecommons.org/licenses/by/2.0), which permits unrestricted use, distribution, and reproduction in any medium, provided the original work is properly cited.
Received: 3I August 2005

Accepted: 27 October 2005

\begin{abstract}
Background: previous studies have shown that non-digestible inulin-type fructan intake can increase intestinal mineral absorption in both humans and animals. However, this stimulatory effect on intestinal absorption may depend on experimental conditions such as duration of fermentable fiber intake, mineral diet levels and animals' physiological status, in particular their age.
\end{abstract}

Objectives: the aim of this study was to determine the effect of inulin intake on $\mathrm{Ca}$ and $\mathrm{Mg}$ absorption in rats at different age stages.

Methods: eighty male Wistar rats of four different ages (2, 5, 10 and 20 months) were randomized into either a control group or a group receiving $3.75 \%$ inulin in their diet for 4 days and then $7.5 \%$ inulin for three weeks. The animals were fed fresh food and water ad libitum for the duration of the experiment. Intestinal absorption of $\mathrm{Ca}$ and $\mathrm{Mg}$ was determined by fecal monitoring using stable isotopic tracers. $\mathrm{Ca}$ and $\mathrm{Mg}$ status was also assessed.

Results: absorption of $\mathrm{Ca}$ and $\mathrm{Mg}$ was significantly lower in the aged rats (10 and $20 \mathrm{mo}$ ) than in the young and adult rat groups. As expected, inulin intake increased $\mathrm{Ca}$ and $\mathrm{Mg}$ absorption in all four rat groups. However, inulin had a numerically greater effect on $\mathrm{Ca}$ absorption in aged rats than in younger rats whereas its effect on $\mathrm{Mg}$ absorption remained similar across all four rat age groups.

Conclusion: the extent of the stimulatory effect of inulin on absorption of Ca may differ according to animal ages. Further studies are required to explore this effect over longer inulin intake periods, and to confirm these results in humans. 


\section{Introduction}

When non-digestible inulin-type fructans reach the large intestine, they are fermented by the local microflora and stimulate the growth of bifidobacteria and lactobacilli, which may have health-promoting functions [1-3]. Several studies have demonstrated that rats fed with prebiotic fructans absorbed more $\mathrm{Ca}$ and $\mathrm{Mg}$ than control rats, despite an increase in total fecal mass [4-6]. Indeed, the products of fructan fermentation can influence the intestinal absorption of $\mathrm{Ca}$ and $\mathrm{Mg}$ in many ways. Short-chain fatty acids (SCFA) are fermentation products that are responsible for lowering the $\mathrm{pH}$ of cecal content, which in turn increases mineral solubility, leading to improved mineral absorption [7]. SCFA can directly influence mineral absorption by forming complexes with the minerals, thereby increase their uptake by the intestinal cells $[8,9]$. It is thought that the bacterial metabolites (e.g. butyrate) can stimulate the intestinal epithelium and increase its absorptive capacity [10]. These various factors are closely linked to the nature of the prebiotic carbohydrates and to experimental conditions [7,11,12]. Inulin has been shown to have generally high and consistent effects on intestinal $\mathrm{Mg}$ absorption in both animals and humans [13], but the effects of inulin on calcium (Ca) absorption seem to be dependent on experimental conditions (dose of inulin, dietary Ca content, experiment duration, animal age and mineral requirements). In this study, we investigated the relationship between animal age and the stimulatory effect of inulin on intestinal absorption and retention of $\mathrm{Ca}$ and $\mathrm{Mg}$ using a stable isotope approach following short-term administration of inulin in rats aged from 2 to 20 months. This is the first time that the effect of inulin is studied in rats using a stable isotope approach

\section{Materials and methods Materials and reagents}

The enriched $\mathrm{Ca}$ isotope $\left({ }^{44} \mathrm{Ca}\right)$ as $\mathrm{CaCO} 3$ and the enriched $\mathrm{Mg}$ isotope $\left({ }^{25} \mathrm{Mg}\right)$ as $\mathrm{MgO}$ were obtained from Chemgas, (Boulogne, France). The atomic abundances of these enriched isotopes were as follows: ${ }^{40} \mathrm{Ca}=3.41 \%$, ${ }^{42} \mathrm{Ca}=0.09 \%,{ }^{43} \mathrm{Ca}=0.03 \%,{ }^{44} \mathrm{Ca}=96.45 \%{ }^{46} \mathrm{Ca}=<$ $0.01 \%{ }^{48} \mathrm{Ca}=0.02 \%$ and ${ }^{24} \mathrm{Mg}=1.6 \%,{ }^{25} \mathrm{Mg}=97.8 \%$, ${ }^{26} \mathrm{Mg}=0.6 \% . \mathrm{HNO}_{3}$ (ultrapure), $\mathrm{Mg}$ and beryllium standard solutions $(1 \mathrm{~g} / \mathrm{L})$ were obtained from Merck (Darmstadt, Germany). All other chemicals were of the highest quality available. Distilled water was used throughout. A Perkin-Elmer 6100DRC system (Perkin-Elmer Instruments, Courteboeuf, France) equipped with a Meinhard nebulizer was used for isotopic measurement, and a Perkin Elmer AA800 (Perkin Elmer Instruments, Courteboeuf, France) was used for total Mg measurement.

\section{Animals and diets}

Eighty male Wistar rats aged 2, 5, 10 or 20 months were purchased from Janvier (Le Genest Saint Ile, France). They
Table I: Diet composition (g/kg) during the experiment

\begin{tabular}{lccc}
\hline & Control diet & \multicolumn{2}{c}{ Inulin diets } \\
& & $3.75 \%$ & $7.5 \%$ \\
\hline Wheat starch & $\mathbf{6 5 0}$ & $\mathbf{6 1 2 . 5}$ & $\mathbf{5 7 5}$ \\
Casein & 200 & 200 & 200 \\
Corn oil & 50 & 50 & 50 \\
Cellulose & 50 & 50 & 50 \\
Mineral mix (AIN 1993)a & 35 & 35 & 35 \\
Vitamin mix (AIN 1993)b & 10 & 10 & 10 \\
DL-Methionine & 3 & 3 & 3 \\
Choline bi-tartrate & 2 & 2 & 2 \\
Inulin & $\mathbf{0}$ & $\mathbf{3 7 . 5}$ & $\mathbf{7 5}$ \\
\hline
\end{tabular}

a: Mineral mix AIN 1993 ensures the following mineral levels in the diets (mg/kg): Na, 1020; K, 3600; P, 4000; Ca, 5000; Mg, 500; Zn, 30; $\mathrm{Fe}, 35 ; \mathrm{Cu}, 6$; Mn, 54; Se, 0.1; I, 0.2; Cr, 2.

b: Vitamin mix AIN 1993 ensures the following mineral levels in the diets $(\mathrm{mg} / \mathrm{kg})$ : thiamine, 6; riboflavine, 6; pyridoxine, 7; nicotinic acid, 30; calcium pantothenate, 16; folic acid, 2; D-biotin: 0.2 ; and $(\mu \mathrm{g} / \mathrm{kg}$ ) cyanocobalamine (vitamin BI2), 10; vitamin $\mathrm{K}, 50$; and (IU/kg) vitamin A, 4000; vitamin E, 50; vitamin D, 1000.

were fed a commercial pellet diet (Ssniff R/S-breeding until $3 \mathrm{mo}$, then Ssniff R/S maintenance from 3 to $24 \mathrm{mo}$ age). Two groups were formed for each age bracket to receive either a control diet or a semi-purified diet containing inulin until the end of the experiment. The composition of these two diets is given in Table 1. Tested inulin was purchased from Orafti, Tienen, Belgium (Raftaline $^{\circledast}$ ). The target $\mathrm{Ca}$ and $\mathrm{Mg}$ levels in these diets were $5000 \mathrm{mg} \mathrm{Ca} / \mathrm{kg}$ and $500 \mathrm{mg} \mathrm{Mg} / \mathrm{Kg}$ diet. Powder diet (100 g) was made up with $100 \mathrm{ml}$ of distilled water to form a kind of semi-liquid food prepared on-site each day. Chemical analysis of the diets offered confirmed the expected $\mathrm{Ca}$ and $\mathrm{Mg}$ contents in the experimental diets: $5107 \mathrm{mg} \mathrm{Ca} / \mathrm{kg}$ and $5050 \mathrm{mg} \mathrm{Ca} / \mathrm{kg}$, and $495 \mathrm{mg} \mathrm{Mg} / \mathrm{kg}$ and $514 \mathrm{mg} \mathrm{Mg} / \mathrm{kg}$ in the control and inulin diets, respectively. Chemical analysis showed that the inulin contained approximately $40 \mathrm{mg} \mathrm{Ca} / \mathrm{kg}$ and less than $1 \mathrm{mg}$ $\mathrm{Mg} / \mathrm{kg}$. Dietary inulin level was maintained at 3.75\% during the first 4 days and then $7.5 \%$ from day 5 until the end of the experiment. The 8 rat groups were given fresh food and water daily, made available ad libitum. Food consumption and body weight were recorded weekly. Throughout the experiment, the rats were housed two per cage (wire-bottomed to limit coprophagy) in a temperature-controlled room $\left(22^{\circ} \mathrm{C}\right)$ with dark period from 08:00 pm to 08:00 am. Total experiment duration was 30 days. All procedures complied with the Institute's ethical guidelines on the care and use of laboratory animals.

\section{Preparation of stable isotope solution}

$215 \mathrm{mg}$ of the ${ }^{44} \mathrm{Ca}$ (in carbonate form $=508 \mathrm{mg}$ ) and 255 $\mathrm{mg}$ of the ${ }^{25} \mathrm{Mg}$ (in oxide form $=412 \mathrm{mg}$ ) were first individually moistened with $2 \mathrm{ml}$ of distilled water. One $\mathrm{ml}$ of 
Table 2: Effect of age and inulin intake and their interaction on cecum fermentation parameters and cecal Ca and Mg levels in rats

\begin{tabular}{|c|c|c|c|c|c|c|c|c|c|c|c|}
\hline & Cont 3 Mo & Cont 6 Mo & Cont II Mo & Cont 21 Mo & Inulin 3 Mo & Inulin 6 Mo & Inulin II Mo & Inulin 2I Mo & inulin & age & interaction \\
\hline Cecal content pH & $6.92 \pm 0.24$ & $6.87 \pm 0.17$ & $6.72 \pm 0.58$ & $6.62 \pm 0.31$ & $5.71 \pm 0.58$ & $5.41 \pm 0.22$ & $5.64 \pm 0.37$ & $5.57 \pm 0.22$ & $<0.0001$ & NS & NS \\
\hline Cecal content, $\mathrm{g}$ & $2.20 \pm 0.35$ & $2.34 \pm 0.68$ & $2.53 \pm 0.97$ & $2.86 \pm 0.74$ & $6.18 \pm 1.68$ & $6.46 \pm 1.57$ & $7.09 \pm 2.31$ & $7.10 \pm 1.91$ & $<0.0001$ & NS & NS \\
\hline Cecal wall, $g$ & $0.87 \pm 0.07$ & $1.11 \pm 0.22$ & $1.32 \pm 0.29$ & $1.25 \pm 0.15$ & $1.80 \pm 0.37$ & $2.32 \pm 0.29$ & $2.51 \pm 0.39$ & $2.46 \pm 0.30$ & $<0.0001$ & NS & NS \\
\hline Acetate, $\mu \mathrm{mol} /$ cecum & $22.4 \pm 6.3$ & $24.5 \pm 9.4$ & $24.4 \pm 11.8$ & $28.0 \pm 8.5$ & $49.2 \pm 22.3$ & $70.4 \pm 16.7$ & $54.3 \pm 17.3$ & $63.5 \pm 11.4$ & $<0.0001$ & 0.033 & NS \\
\hline Propionate, $\mu \mathrm{mol} / \mathrm{cecum}$ & $5.49 \pm 1.48$ & $6.31 \pm 2.20$ & $5.11 \pm 2.10$ & $6.11 \pm 1.72$ & $15.56 \pm 12.29$ & $12.84 \pm 5.04$ & $9.96 \pm 4.86$ & $11.26 \pm 3.92$ & $<0.0001$ & NS & NS \\
\hline Butyrate, $\mu \mathrm{mol} /$ cecum & $9.90 \pm 2.70$ & $8.63 \pm 3.10$ & $6.37 \pm 2.78$ & $8.01 \pm 3.38$ & $48.13 \pm 25.12$ & $69.51 \pm 32.50$ & $39.98 \pm 18.42$ & $43.15 \pm 8.63$ & $<0.0001$ & 0.018 & 0.037 \\
\hline Total SCFA, $\mu \mathrm{mol} / \mathrm{cecum}$ & $37.8 \pm 9.1$ & $39.5 \pm 13.5$ & $35.9 \pm 15.9$ & $42.2 \pm 12.6$ & $112.9 \pm 50.8$ & $152.8 \pm 40.0$ & $104.2 \pm 27.7$ & $117.9 \pm 17.3$ & $<0.0001$ & 0.024 & 0.049 \\
\hline
\end{tabular}

Values are mean $\pm S D, n=10$ animals.

The rats were received inulin ( $7.5 \%)$ for 4 weeks before cecal parameters assessment.

$\mathrm{HCl} 12 \mathrm{~N}$ (ultrapure) was added to the ${ }^{44} \mathrm{Ca}$ suspension and two $\mathrm{ml}$ of $\mathrm{HCl} 12 \mathrm{~N}$ was added to the ${ }^{25} \mathrm{Mg}$ suspension to transform the carbonate and the oxide into soluble chlorides of $\mathrm{Ca}$ and $\mathrm{Mg}$, respectively. Each solution was then diluted with $50 \mathrm{ml}$ of distilled water, both solutions were then mixed, and $\mathrm{pH}$ was adjusted to between 3 and 6 with $1 \mathrm{~N}$ sodium hydroxide solution. The resulting study solution was then completed to $150 \mathrm{ml}$ with distilled water and maintained for several days at $+4{ }^{\circ} \mathrm{C}$ until utilization. Total and isotopic $\mathrm{Ca}$ and $\mathrm{Mg}$ contents were checked before use.

The rats were transferred to metabolic cages and housed individually three days before the beginning of the isotopic balance study to allow them to adapt to their new environment. Animals received by gavage about $1.7 \mathrm{ml}$ of isotopic solution. The urine and faeces of each rat were quantitatively collected for four consecutive days, and excreted isotopes in these two media and in the gavage solution were quantitatively determined by ICP/MS, as described below.

\section{Sampling procedures}

The rats were sacrificed just after the dark period (between 08:00 am and 10:00 am), i.e. at a time when cecal fermentation was still very active. After anesthesia (40 mg sodium pentobarbital/kg body weight), blood was withdrawn from the abdominal aorta, placed into tubes containing sodium heparin and centrifuged at $1,000 \mathrm{~g}$ for $10 \mathrm{~min}$ utes. Plasma samples were stored at $4{ }^{\circ} \mathrm{C}$ for mineral analysis. The cecum, complete with contents, was removed and weighed (total cecal weight). The cecal wall was flushed clean with ice-cold saline, blotted on filter paper, and weighed (cecal wall weight). For each rat, duplicate samples of cecal contents were collected into $2 \mathrm{ml}$ microfuge tubes and immediately frozen at $-20^{\circ} \mathrm{C}$ until analysis. The $\mathrm{pH}$ of cecal content was determined on site using a Sentron pH-system 1001 portable pH-meter (Sentron Europe B.V. Ac Roden, The Netherlands). Supernatants of the digestive contents were obtained by centrifuging one of the two microfuge tubes at 20,000 $\mathrm{g}$ for 10 minutes at $4^{\circ} \mathrm{C}$, and then frozen until analysis. One tibia was also sampled for $\mathrm{Ca}$ and $\mathrm{Mg}$ analysis.

\section{Analytical procedures}

$\mathrm{Ca}$ and $\mathrm{Mg}$ concentrations were determined in the plasma and urine after adequate dilution into $0.1 \%(\mathrm{w} / \mathrm{v})$ lanthanum chloride. Diet aliquots, fecal materials and tibia were dry-ashed $\left(10\right.$ hours at $\left.500^{\circ} \mathrm{C}\right)$ and dissolved with concentrated $\mathrm{HNO}_{3}$ and $\mathrm{H}_{2} \mathrm{O}_{2}$ on a heating plate until complete decoloration. The resulting mineral solutions were set at $10 \mathrm{ml}$ with water and adequately diluted in $0.1 \%$ lanthanum chloride. Mineral concentrations were measured by atomic absorption spectrophotometry (on a Perkin-Elmer AA800) at wavelengths of $422 \mathrm{~nm}$ for Ca and $285 \mathrm{~nm}$ for $\mathrm{Mg}$.

For isotopic ${ }^{44} \mathrm{Ca}$ and ${ }^{25} \mathrm{Mg}$ determination, samples were appropriately diluted before analysis using $1 \% \mathrm{HNO}_{3}$. Ca and $\mathrm{Mg}$ concentration and isotope ratios were determined by ICP-MS using $\mathrm{Ca}$ and $\mathrm{Mg}$ as external standard and beryllium as internal standard. The instrument operating conditions were set as follows after optimization with a solution of $1 \mu \mathrm{g}$ indium/l: RF Power $=1050 \mathrm{~W}$, Nebulizer Ar flow rate $=0.79 \mathrm{~L} / \mathrm{min}$, Auxiliary Ar flow rate $=1.2 \mathrm{~L} /$ min, Outer Ar flow rate $=15 \mathrm{~L} / \mathrm{min}$. Data acquisition parameters were set as follows: Sweeps/reading $=50$, Readings $/$ replicate $=1$, Number of replicates $=3$, Dwell time $=50 \mathrm{~ms}$ for ${ }^{24} \mathrm{Mg}, 75 \mathrm{~ms}$ for ${ }^{9} \mathrm{Be},{ }^{25} \mathrm{Mg},{ }^{26} \mathrm{Mg}$, and ${ }^{44} \mathrm{Ca}, 150 \mathrm{~ms}$ for ${ }^{42} \mathrm{Ca}$ and $300 \mathrm{~ms}$ for ${ }^{43} \mathrm{Ca}$, Scanning mode $=$ peak hopping. DRC operating conditions (for ${ }^{42} \mathrm{Ca},{ }^{43} \mathrm{Ca}$ and $\left.{ }^{44} \mathrm{Ca}\right)$ were as follows: Cell Gas A Flow Rate $=0.5 \mathrm{~L} \mathrm{ammonia} / \mathrm{min}, \mathrm{RPa}=0$, and $\mathrm{RPq}=0.45$.

Cecal SCFA concentrations, including acetic, propionic and butyric acid, were determined by gas-liquid chromatography on portions of supernatant fractions of cecal contents as previously described [14].

\section{Calculations}

$\mathrm{Ca}$ and $\mathrm{Mg}$ each have different stable isotopes with the following natural abundances: ${ }^{40} \mathrm{Ca}=96.941 \%,{ }^{42} \mathrm{Ca}=$ $0.647 \%,{ }^{43} \mathrm{Ca}=0.135 \%,{ }^{44} \mathrm{Ca}=2.086 \%{ }^{46} \mathrm{Ca}=0.004 \%$ 
Table 3: Effect of age and inulin intake and their interaction on intestinal absorption and retention of $\mathrm{Ca}$ in rats

\begin{tabular}{|c|c|c|c|c|c|c|c|c|c|c|c|}
\hline & Cont 3 Mo & Cont 6 Mo & Cont II Mo & Cont 21 Mo & Inulin 3 Mo & Inulin 6 Mo & Inulin II Mo & Inulin 2 I Mo & inulin & age & interaction \\
\hline Administered ${ }^{44} \mathrm{Ca}, \mu \mathrm{g}$ & $1637 \pm 46$ & $1610 \pm 14$ & $1602 \pm 17$ & $1605 \pm 24$ & $1593 \pm 19$ & $1614 \pm 19$ & $162 \mid \pm 25$ & $1626 \pm 22$ & NS & NS & $<0.0005$ \\
\hline Fecal ${ }^{44} \mathrm{Ca}$ enrichment, $\%$ & $12.5 \pm 3.3$ & $17.3 \pm 2.4$ & $20.2 \pm 4.3$ & $18.7 \pm 2.8$ & $10.9 \pm 4.2$ & $17.8 \pm 6.2$ & $17.4 \pm 2.1$ & $21.2 \pm 3.1$ & NS & $<0.0001$ & NS \\
\hline Fecal ${ }^{44} \mathrm{Ca}$ level, $\mu \mathrm{g} / \mathrm{g}$ & $112 \pm 30$ & $182 \pm 35$ & $218 \pm 45$ & $204 \pm 38$ & $76 \pm 30$ & $152 \pm 49$ & $163 \pm 26$ & $188 \pm 26$ & $<0.0001$ & $<0.000$ I & NS \\
\hline Fecal ${ }^{44} \mathrm{Ca}$ excretion, $\mu \mathrm{g}$ & $856 \pm 224$ & $1139 \pm 153$ & $1389 \pm 96$ & $1366 \pm 115$ & $541 \pm 223$ & $926 \pm 142$ & $1207 \pm 195$ & $1192 \pm 142$ & $<0.0001$ & $<0.0001$ & NS \\
\hline Intestinal ${ }^{44} \mathrm{Ca}$ absorption, $\mu \mathrm{g}$ & $781 \pm 206$ & $471 \pm 153$ & $213 \pm 90$ & $239 \pm 117$ & $1052 \pm 222$ & $689 \pm 142$ & $413 \pm 202$ & $434 \pm 143$ & $<0.0001$ & $<0.0001$ & NS \\
\hline Intestinal ${ }^{44} \mathrm{Ca}$ absorption, \% & $47.8 \pm 12.9$ & $29.3 \pm 9.4$ & $13.3 \pm 5.6$ & $14.9 \pm 7.3$ & $66.1 \pm 13.9$ & $42.7 \pm 8.8$ & $25.4 \pm 12.4$ & $26.7 \pm 8.7$ & $<0.0001$ & $<0.0001$ & NS \\
\hline Urinary ${ }^{44} \mathrm{Ca}$ enrichment, $\%$ & $17.4 \pm 6.5$ & $20.6 \pm 6.7$ & $14.8 \pm 3.1$ & $16.9 \pm 3.9$ & $13.7 \pm 3.3$ & $17.5 \pm 6.7$ & $18.6 \pm 4.2$ & $18.5 \pm 4.1$ & NS & NS & 0.0569 \\
\hline Urinary ${ }^{44} \mathrm{Ca}$ excretion, $\mu \mathrm{g}$ & $15.3 \pm 5.9$ & $14.8 \pm 6.0$ & $25.8 \pm 10.7$ & $28.1 \pm 7.9$ & $23.5 \pm 7.2$ & $21.8 \pm 9.9$ & $49.0 \pm 11.8$ & $40.3 \pm 12.5$ & $<0.0001$ & $<0.000$ I & 0.036 \\
\hline${ }^{44} \mathrm{Ca}$ retention, $\mu \mathrm{g}$ & $765 \pm 204$ & $456 \pm 153$ & $188 \pm 92$ & $212 \pm 113$ & $1029 \pm 219$ & $667 \pm 135$ & $364 \pm 203$ & $394 \pm 145$ & $<0.0001$ & $<0.0001$ & NS \\
\hline${ }^{44} \mathrm{Ca}$ retention, $\%$ & $46.9 \pm 12.8$ & $28.3 \pm 9.5$ & $11.7 \pm 5.7$ & $13.2 \pm 7.1$ & $64.6 \pm 13.8$ & $41.3 \pm 8.3$ & $22.4 \pm 12.4$ & $24.2 \pm 8.9$ & $<0.0001$ & $<0.0001$ & NS \\
\hline
\end{tabular}

Values are mean $\pm S D, n=10$ animals.

The rats were given ${ }^{44} \mathrm{Ca}$ after 14 days of inulin intake (7.5\%), and fecal non-absorbed ${ }^{44} \mathrm{Ca}$ isotope was determined in a $4 \mathrm{~d}$ feces and urine pools.

${ }^{48} \mathrm{Ca}=0.187 \%$ and ${ }^{24} \mathrm{Mg}=78.99 \%,{ }^{25} \mathrm{Mg}=10.00 \%$ and ${ }^{26} \mathrm{Mg}=11.01 \%$ [15]. ${ }^{44} \mathrm{Ca}$ and ${ }^{25} \mathrm{Mg}$ isotopic enrichments were obtained, respectively, from the following equations: $\left({ }^{44} \mathrm{Ca} /{ }^{43} \mathrm{Ca}\right.$ measured ratio $-{ }^{44} \mathrm{Ca} /{ }^{43} \mathrm{Ca}$ baseline ratio $) /\left({ }^{44} \mathrm{Ca} /{ }^{43} \mathrm{Ca}\right.$ baseline ratio $)$ and $\left({ }^{25} \mathrm{Mg} /{ }^{26} \mathrm{Mg}\right.$ measured ratio $-{ }^{25} \mathrm{Mg} /{ }^{26} \mathrm{Mg}$ baseline ratio $) /\left({ }^{25} \mathrm{Mg} /{ }^{26} \mathrm{Mg}\right.$ baseline ratio).

Non-absorbed ${ }^{44} \mathrm{Ca}$ and ${ }^{25} \mathrm{Mg}$ isotopes in the fecal or urine samples (coming only from the ${ }^{44} \mathrm{Ca}$ or ${ }^{25} \mathrm{Mg}$ isotope labels) were calculated as follows:

for ${ }^{44} \mathrm{Ca}(\mathrm{mg})=($ total fecal or urine $\mathrm{Ca}(\mathrm{mg}) \times$ (natural abundance ${ }^{44} \mathrm{Ca} \times$ enriched $\left.{ }^{44} \mathrm{Ca}\right) /(1+$ (natural abundance ${ }^{44} \mathrm{Ca} \times$ enriched $\left.{ }^{44} \mathrm{Ca}\right)$;

for ${ }^{25} \mathrm{Mg}(\mathrm{mg})=($ total fecal or urine $\mathrm{Mg}(\mathrm{mg}) \times$ (natural abundance ${ }^{25} \mathrm{Mg} \times$ enriched $\left.25 \mathrm{Mg}\right) /(1+$ (natural abundance ${ }^{25} \mathrm{Mg} \times$ enriched $\left.{ }^{25} \mathrm{Mg}\right)$ ).

Calculations were also made directly from ICP-MS data. The two modes of calculation give the same results when the ICP-MS quantitative procedure is used [16].

Intestinal absorption of ${ }^{44} \mathrm{Ca}$ and ${ }^{25} \mathrm{Mg}$ was then calculated as administered ${ }^{44} \mathrm{Ca}$ or ${ }^{25} \mathrm{Mg}-{ }^{44} \mathrm{Ca}$ or ${ }^{25} \mathrm{Mg}$ excreted in the feces, and retention of ${ }^{44} \mathrm{Ca}$ and ${ }^{25} \mathrm{Mg}$ was calculated as administered ${ }^{44} \mathrm{Ca}$ or ${ }^{25} \mathrm{Mg}-{ }^{44} \mathrm{Ca}$ or ${ }^{25} \mathrm{Mg}$ excreted in the feces and in the urine.

Total cecal SCFA content ( $\mu \mathrm{mol} /$ cecum) was calculated as the supernatant SCFA concentration $(\mu \mathrm{mol} / \mathrm{ml}) \times$ cecal water ( $\mathrm{ml} /$ cecum).

Soluble Ca and Mg levels in the cecal contents were determined on the supernatant concentration $(\mu \mathrm{g} / \mathrm{ml})$, and soluble $\mathrm{Ca}$ and $\mathrm{Mg}$ contents per cecum were calculated as $(\mu \mathrm{g} \mathrm{Ca} / \mathrm{ml}$ or $\mu \mathrm{g} \mathrm{Mg} / \mathrm{ml}) \times$ cecal water $(\mathrm{ml})$.

\section{Data analysis}

Values are given as means $\pm \mathrm{SD}$, and data were tested by 2way ANOVA using the General Linear Models procedure of the Super ANOVA package (Abacus, Berkeley, CA). Post-hoc comparisons were performed using Fisher's least significant difference procedures. Differences of $\mathrm{p}<0.05$ were considered statistically significant. Simple linear correlation analysis was used to assess the relationships between intestinal absorption of $\mathrm{Ca}$ and $\mathrm{Mg}$ and other relevant parameters. Values of $\mathrm{p}<0.05$ were considered statistically significant.

\section{Results}

\section{Food intake and growth rate}

Inulin intake at the dose of $7.5 \%$ showed only a tendency to decrease animal food intake in this study. The slight decrease in food intake in inulin-fed rats led to a non-significantly lower growth rate $(p<0.10)$ towards the end of the experiment in inulin-fed rats compared to controls. The lower calorific value of the inulin diets (-4\%) compared to the control diets may also be responsible for this reduced weight gain. In addition, food intake decreased significantly with increasing age, as expected (data not shown).

\section{Cecal fermentation parameters and total and cecal soluble Ca and $\mathrm{Mg}$ levels (table 2)}

As expected, inulin intake significantly increased cecal wall weight and cecal content and significantly decreased the $\mathrm{pH}$ of cecal content. These variables did not change with rat age. In addition, inulin intake considerably increased the individual and total pools of SCFA in the cecal contents $(\mathrm{p}<0.0001)$. The effect of age on these SCFA pools was less clear. No significant age-related difference was observed amongst the control group rats, whereas in the inulin-fed group, the intestinal bacteria produced higher acetate, butyrate and total SCFA in the rats aged 10 mo than in the three other groups $(\mathrm{p}<0.05)$. 
Table 4: Effect of age and inulin intake and their interaction on intestinal absorption and retention of $\mathrm{Mg}$ in rats

\begin{tabular}{|c|c|c|c|c|c|c|c|c|c|c|c|}
\hline & Cont 3 Mo & Cont 6 Mo & Cont II Mo & Cont 21 Mo & Inulin 3 Mo & Inulin 6 Mo & Inulin II Mo & Inulin 21 Mo & inulin & age & interaction \\
\hline Administered ${ }^{25} \mathrm{Mg}, \mu \mathrm{g}$ & $2553 \pm 71$ & $2511 \pm 22$ & $2499 \pm 26$ & $2504 \pm 38$ & $2485 \pm 30$ & $2518 \pm 30$ & $2527 \pm 39$ & $2536 \pm 35$ & NS & NS & $<0.0005$ \\
\hline Fecal ${ }^{25} \mathrm{Mg}$ enrichment, $\%$ & $47.9 \pm 7.1$ & $51.9 \pm 7.4$ & $54.6 \pm 12.3$ & $54.1 \pm 8.1$ & $33.9 \pm 20.3$ & $41.0 \pm 19.9$ & $47.4 \pm 13.9$ & $65.7 \pm 17.6$ & NS & 0.0007 & 0.027 \\
\hline Fecal $25 \mathrm{Mg}$ level, $\mu \mathrm{g} / \mathrm{g}$ & $149 \pm 26$ & $184 \pm 34$ & $205 \pm 44$ & $204 \pm 38$ & $51 \pm 33$ & $70 \pm 35$ & $91 \pm 31$ & $120 \pm 35$ & $<0.0001$ & $<0.0001$ & NS \\
\hline Fecal ${ }^{25} \mathrm{Mg}$ excretion, $\mu \mathrm{g}$ & $|138 \pm 20|$ & $1157 \pm 229$ & $|3| \mid \pm 200$ & $1366 \pm 177$ & $358 \pm 224$ & $430 \pm 206$ & $673 \pm 205$ & $757 \pm 184$ & $<0.0001$ & $<0.0001$ & NS \\
\hline Intestinal ${ }^{25} \mathrm{Mg}$ absorption, $\mu \mathrm{g}$ & $1415 \pm 187$ & $1354 \pm 225$ & $1188 \pm 199$ & $1137 \pm 175$ & $2127 \pm 224$ & $2087 \pm 208$ & $1855 \pm 232$ & $1780 \pm 186$ & $<0.0001$ & $<0.0001$ & NS \\
\hline Intestinal ${ }^{25} \mathrm{Mg}$ absorption \% & $55.5 \pm 7.5$ & $54.0 \pm 9.0$ & $47.5 \pm 8.0$ & $45.4 \pm 7.0$ & $85.6 \pm 8.9$ & $82.9 \pm 8.2$ & $73.3 \pm 8.4$ & $70.2 \pm 7.2$ & $<0.0001$ & $<0.0001$ & NS \\
\hline Urinary ${ }^{25} \mathrm{Mg}$ enrichment, \% & $29.3 \pm 2.7$ & $29.1 \pm 3.5$ & $28.0 \pm 3.7$ & $28.2 \pm 2.32$ & $34.2 \pm 3.8$ & $35.5 \pm 2.4$ & $33.5 \pm 3.7$ & $36.7 \pm 6.5$ & $<0.0001$ & NS & NS \\
\hline Urinary ${ }^{25} \mathrm{Mg}$ excretion, $\mu \mathrm{g}$ & $398 \pm 64$ & $323 \pm 36$ & $298 \pm 80$ & $292 \pm 88$ & $699 \pm 91$ & $792 \pm 167$ & $633 \pm 146$ & $551 \pm 164$ & $<0.0001$ & 0.003 & NS \\
\hline${ }^{25} \mathrm{Mg}$ retention, $\mu \mathrm{g}$ & $1017 \pm 189$ & $1031 \pm 225$ & $890 \pm 179$ & $845 \pm 142$ & $1428 \pm 216$ & $1295 \pm 192$ & $122 \mid \pm 242$ & $1228 \pm 165$ & $<0.0001$ & 0.011 & NS \\
\hline${ }^{25} \mathrm{Mg}$ retention, \% & $39.8 \pm 7.3$ & $41.1 \pm 9.0$ & $35.6 \pm 7.1$ & $33.7 \pm 5.7$ & $57.8 \pm 8.9$ & $51.5 \pm 7.8$ & $48.3 \pm 9.2$ & $48.4 \pm 6.5$ & $<0.0001$ & 0.008 & NS \\
\hline
\end{tabular}

Values are mean $\pm S D, n=10$ animals.

The rats were given ${ }^{25} \mathrm{Mg}$ after 14 days of inulin intake (7.5\%), and fecal non-absorbed ${ }^{25} \mathrm{Mg}$ isotope was determined in a $4 \mathrm{~d}$ feces and urine pools.

\section{Intestinal absorption and retention of calcium (table 3)}

The amount of gavaged ${ }^{44} \mathrm{Ca}$ was about $1.60 \mathrm{mg} / \mathrm{rat}$, which led to a fecal ${ }^{44} \mathrm{Ca}$ enrichment of $10 \%$ to $20 \%$ in the 4-day feces pool. Fecal ${ }^{44} \mathrm{Ca}$ excretion expressed as $\mathrm{mg} / \mathrm{g}$ of feces or as $\mathrm{mg} /$ day increased significantly with age. Consequently, net (mg) and relative (\%) ${ }^{44} \mathrm{Ca}$ absorption were significantly lower in the aged rats than in the young adult or adult rats. In addition, urinary ${ }^{44} \mathrm{Ca}$ excretion (mg) increased significantly with age. Consequently, net (mg) and relative (\%) ${ }^{44} \mathrm{Ca}$ retention were considerably lower in the aged rats than in the young adult or adult rats. Inulin intake significantly decreased fecal ${ }^{44} \mathrm{Ca}$ excretion, expressed as $\mu \mathrm{g} / \mathrm{g}$ of feces or as $\mu \mathrm{g}$, in all groups. Consequently, inulin intake significantly increased net (mg) and relative (\%) ${ }^{44} \mathrm{Ca}$ absorption. Moreover, inulin intake increased urinary ${ }^{44} \mathrm{Ca}$ excretion $(\mathrm{mg})$. Lastly, inulin intake significantly increased net $(\mathrm{mg})$ and relative (\%) ${ }^{44} \mathrm{Ca}$ retention in the four age-related groups compared to the control diet groups.

Intestinal absorption and retention of magnesium (table 4) The amount of gavaged ${ }^{25} \mathrm{Mg}$ was about $2.50 \mathrm{mg} / \mathrm{rat}$, which led to a fecal ${ }^{25} \mathrm{Mg}$ enrichment of $35 \%$ to $65 \%$ in the 4 -day feces pool. Fecal ${ }^{25} \mathrm{Mg}$ excretion expressed as $\mathrm{mg} / \mathrm{g}$ of feces or as $\mathrm{mg}$ increased significantly with age. Consequently, net (mg) and relative (\%) ${ }^{25} \mathrm{Mg}$ absorption were significantly lower in the aged rats than in the young adult or adult rats. In addition, urinary ${ }^{25} \mathrm{Mg}$ excretion (mg) increased significantly with age. Consequently, net (mg) and relative (\%) ${ }^{25} \mathrm{Mg}$ retention were significantly lower in the aged rats than in the young adult or adult rats. As expected, inulin intake significantly decreased fecal ${ }^{25} \mathrm{Mg}$ excretion, expressed as $\mu \mathrm{g} / \mathrm{g}$ of feces or as $\mu \mathrm{g}$, in all groups. Consequently, inulin intake significantly increased net $(\mathrm{mg})$ and relative $(\%){ }^{25} \mathrm{Mg}$ absorption. Similarly, inulin intake increased urinary ${ }^{25} \mathrm{Mg}$ excretion (mg). However, inulin intake led to significantly higher net $(\mathrm{mg})$ and relative $(\%){ }^{25} \mathrm{Mg}$ retention in all four groups compared to the control diet.

\section{Calcium and magnesium status (table 5)}

Mean plasma Ca varied from 95 to $102 \mathrm{mg} / \mathrm{L}$, showing a tendency to increase with inulin intake $(+2 \%, \mathrm{p}=0.0601)$ and to decrease with increasing age $(-1 \%, \mathrm{p}=0.0619)$. Mean bone Ca varied from 202 to $228 \mathrm{mg} / \mathrm{g}$ dry weight, and was unaffected by inulin intake. However, mean bone Ca increased significantly with increasing age. Mean plasma $\mathrm{Mg}$ varied from 16.9 to $18.2 \mathrm{mg} / \mathrm{L}$, showing a tendency to increase with inulin intake $(+3 \%, \mathrm{p}=$ 0.0570 ). However, mean plasma Mg was not modified by age. Plasma $\mathrm{Mg}$ increased in the inulin-fed aged rats $(+6.7 \%)$, whereas there was no increase in the young and adult rats $(-0.3 \%)$. Mean red blood cell $\mathrm{Mg}$ levels varied from 42.5 to $45.4 \mathrm{mg} / \mathrm{L}$ and remained unchanged when age increases or under inulin intake. Mean bone $\mathrm{Mg}$ levels varied from 3.72 to $3.92 \mathrm{mg} / \mathrm{g}$ dry weight, decreasing significantly with aging $(\mathrm{p}<0.0001)$. However, mean bone $\mathrm{Mg}$ was unaffected by inulin intake.

\section{Discussion}

Previous studies have repeatedly shown that intake of different inulin-type fructans can variably increase mineral intestinal absorption in humans and animals [4,5,17-19]. Indeed, inulin-type fructans strongly and consistently increase intestinal $\mathrm{Mg}$ absorption [12], whereas their effect on $\mathrm{Ca}$ absorption seems to be dependent on experimental conditions such as inulin type, dietary Ca levels, duration of fructan intake [20-22] and the animals' physiological state, particularly age. It is well known that the absorption mechanisms of $\mathrm{Ca}$ and $\mathrm{Mg}$ differ considerably $[23,24]$, which may explain the observed differences between these two minerals in terms of inulin effect. In this study, we investigated the enhancing effect of fructan intake on Ca and $\mathrm{Mg}$ intestinal absorption and balance in rats of different ages.

I - Effect of animal age and inulin intake on Ca absorption Our results clearly showed that aged rats exhibited less efficient intestinal absorption and retention of $\mathrm{Ca} .{ }^{44} \mathrm{Ca}$ absorption ranged from $48 \%$ without inulin to $66 \%$ 
Table 5: Effect of age and inulin intake and their interaction on status biomarkers of $\mathrm{Ca}$ and $\mathrm{Mg}$ in rats

\begin{tabular}{|c|c|c|c|c|c|c|c|c|c|c|c|}
\hline & Cont $3 \mathrm{M}$ & Cont $6 \mathrm{M}$ & Cont II M & Cont $21 \mathrm{M}$ & Inulin 3 M & Inulin 6 M & Inulin II M & Inulin 21 M & inulin & age & interaction \\
\hline Plasma Ca, mg/L & $98 \pm 4$ & $98 \pm 5$ & $95 \pm 6$ & $100 \pm 5$ & $102 \pm 5$ & $99 \pm 4$ & $98 \pm 3$ & $100 \pm 4$ & $\underline{0.0601}$ & $\underline{0.0619}$ & NS \\
\hline Tibia weight, $\mathrm{mg} d w$ & $480 \pm 42$ & $630 \pm 80$ & $717 \pm 89$ & $630 \pm 93$ & $489 \pm 66$ & $617 \pm 66$ & $841 \pm 92$ & $648 \pm 47$ & 0.042 & $<0.0001$ & 0.023 \\
\hline Bone Ca, mg/g dw & $207 \pm 21$ & $214 \pm 15$ & $216 \pm 15$ & $215 \pm 21$ & $205 \pm 13$ & $215 \pm 18$ & $202 \pm 14$ & $228 \pm 7$ & NS & 0.018 & $\underline{0.0639}$ \\
\hline Plasma Mg, mg/L & $17.9 \pm 1.1$ & $17.7 \pm 1.1$ & $17.2 \pm 1.0$ & $16.9 \pm 1.3$ & $17.6 \pm 1.1$ & $17.9 \pm 1.3$ & $18.2 \pm 1.5$ & $18.2 \pm 1.7$ & $\underline{0.0570}$ & NS & NS \\
\hline Erythrocyte Mg, mg/L & $45.4 \pm 3.8$ & $44.2 \pm 4.7$ & $42.5 \pm 3.4$ & $43.4 \pm 3.0$ & $44.9 \pm 4.9$ & $43.8 \pm 2.5$ & $44.3 \pm 3.6$ & $43.8 \pm 3.9$ & NS & NS & NS \\
\hline Bone $\mathrm{Mg}, \mathrm{mg} / \mathrm{g} \mathrm{dw}$ & $3.92 \pm 0.10$ & $3.79 \pm 0.08$ & $3.72 \pm 0.08$ & $3.76 \pm 0.08$ & $3.91 \pm 0.10$ & $3.72 \pm 0.07$ & $3.73 \pm 0.09$ & $3.72 \pm 0.09$ & NS & $<0.0001$ & NS \\
\hline
\end{tabular}

Values are mean $\pm S D, n=10$ animals.

under inulin intake in the young and adult rats and from $15 \%$ without inulin to $27 \%$ under inulin intake in the old and very old rats. This decline in Ca absorption with age is not new, and has already been reported in animal and human studies [25-27] and is largely confirmed in this study. This decline is primarily due to an energy- and vitamin D-dependent Ca transport component in the elderly [28]. Our results clearly showed that inulin intake increased the efficiency of Ca intestinal absorption and retention. The mean ${ }^{44} \mathrm{Ca}$ absorption in the four rat control groups was $26.3 \%$ compared to $40.2 \%$ in the four inulin-fed groups, with an overall increase in ${ }^{44} \mathrm{Ca}$ absorption of $53 \%$. These results are in agreement with literature data showing that the effect of inulin on Ca absorption seems to be optimal in the early weeks, then decreasing gradually with experiment duration $[20,29,30]$. One possible explanation for this phenomenon is a down-regulation of the active pathway of intestinal Ca absorption after several weeks of feeding inulin, as previously reported $[31,32]$.

\section{2 - Effect of animal age and inulin intake on $\mathrm{Mg}$ absorption}

Our results showed that aged rats exhibited less efficient intestinal absorption and retention of $\mathrm{Mg} .{ }^{25} \mathrm{Mg}$ absorption ranged from $56 \%$ without inulin to $86 \%$ under inulin intake in the young and adult rats and from $45 \%$ without inulin to $70 \%$ under inulin intake in the old and very old rats. This decline in Mg absorption with age is not well documented in the literature in either animal or human studies. Few, if any, incomplete studies have reported an age effect on $\mathrm{Mg}$ absorption [33-35], and the results are inconsistent. Hence, to our knowledge, this is the first robust report to clearly show that $\mathrm{Mg}$ absorption decreases with age in the rat. Although $\mathrm{Mg}$ absorption is generally described as a passive phenomenon, one component of this absorption remains under hormonal control $[36,37]$, which may explain the observed results. Our results clearly showed that inulin intake considerably increased $\mathrm{Mg}$ intestinal absorption and retention efficiency. Mean ${ }^{25} \mathrm{Mg}$ absorption in the four rat control groups was $50.6 \%$, compared to $78.0 \%$ in the four corresponding inulin-fed rat groups, with an overall increase in ${ }^{25} \mathrm{Mg}$ absorption of $54 \%$. These results are in agreement with literature data showing that inulin intake considerably increases $\mathrm{Mg}$ absorption in animals and humans (see recent review [13]).

\section{3 - Modulation of the stimulatory inulin effect on $\mathrm{Ca}$ and Mg absorption with rat age}

Since $\mathrm{Ca}$ absorption is generally well controlled, the observed absorption increase under inulin intake may be down-regulated (known as a feed-back phenomenon) in adult rats. Thus, given that Ca absorption is low and the adaptative phenomenon less well controlled in aged rats, we hypothesized that inulin intake would lead to a much greater increase in Ca absorption in aged rats than in the young or adult rats. Conversely, since $\mathrm{Mg}$ absorption is only weakly controlled with a generally consistent increase under inulin intake in adult rats, we hypothesized that inulin intake would increase $\mathrm{Mg}$ absorption in both aged rats and young or adult rats to the same extent.

The relative increase in ${ }^{44} \mathrm{Ca}$ absorption under inulin intake was $41.5 \%$ and $84.5 \%$ in the younger ( 3 and 6 mo old) and older rats (11 and 21 mo old), respectively (figure 1). Although these increase percents are numerically more important in the older rats than in the younger rats, there was no statistically significant interaction between age and inuline. It is highly possible that the number of animals used in this experiment was not enough to reach significant level. Furthermore, the relative increase in ${ }^{25} \mathrm{Mg}$ absorption under inulin intake was $53.5 \%$ and $54.5 \%$ in the younger and older rats, respectively (figure 1 ). This indicates that the stimulatory effect of inulin on ${ }^{25} \mathrm{Mg}$ absorption was not age-dependent. It is possible that inulin intake may lead to a higher increase in ${ }^{44} \mathrm{Ca}$ absorption in the older rats than in the younger rats, whereas inulin intake leads to a similar increase in ${ }^{25} \mathrm{Mg}$ absorption in young, adult and aged rats, thus confirming the hypothesis we formulated for this study.

In conclusion, as expected, our results confirmed that short-term inulin intake stimulates the absorption of both $\mathrm{Ca}$ and Mg. Furthermore, not only these results confirmed that $\mathrm{Ca}$ absorption declines considerably with age but also showed for the first time that $\mathrm{Mg}$ absorption also declines 

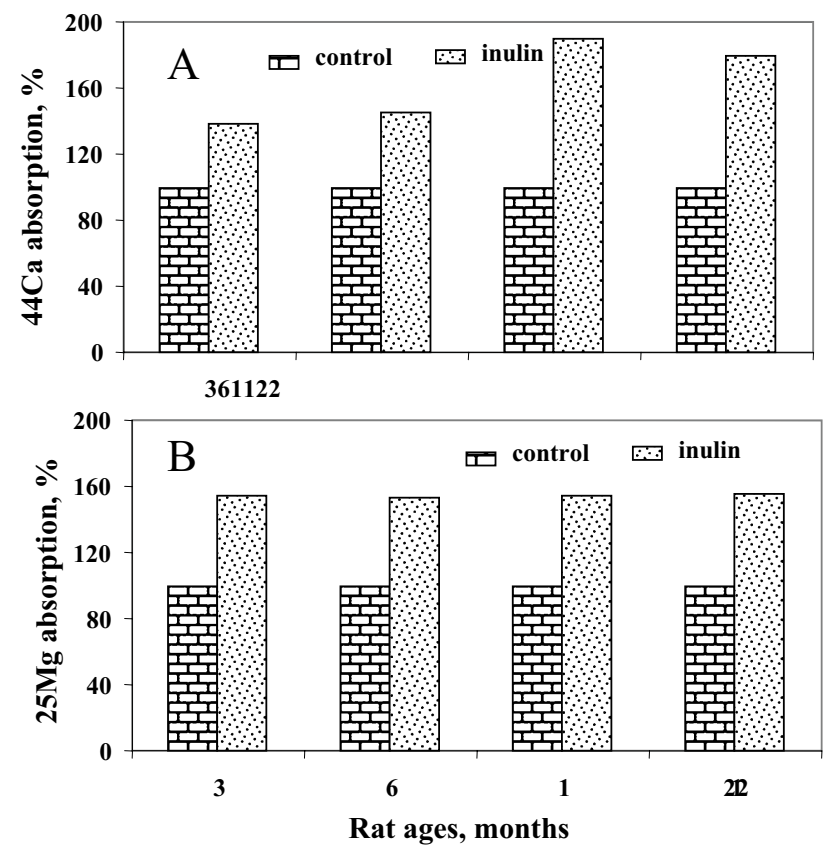

Figure I

Stimulatory effect of dietary inulin intake on intestinal absorption of ${ }^{44} \mathrm{Ca}$ and ${ }^{25} \mathrm{Mg}$ in rats of different ages. Intestinal ${ }^{44} \mathrm{Ca}$ absorption $(\mathrm{A})$ and ntestinal ${ }^{25} \mathrm{Mg}$ absorption (B) in the control groups was normalized to $100 \%$ for each age group. The stimulatory effect of inulin (\%) for a given age group was calculated as follows: 100* (intestinal absorption in the inulin-fed age group/intestinal absorption in the same age group without inulin). The rats were given ${ }^{44} \mathrm{Ca}$ and $25 \mathrm{Mg}$ after 14 days of inulin intake (7.5\%), and fecal nonabsorbed isotopes were determined in a $4 \mathrm{~d}$ feces pool.

with age in the rat. Moreover, these results confirmed our hypothesis of a greater stimulatory effect of inulin on $\mathrm{Ca}$ absorption in aged rats than in the young or adult rats, and a similar stimulatory effect of inulin on $\mathrm{Mg}$ absorption in aged rats and young and adult rats. Further studies are required to explore this effect on longer inulin intake periods and to validate these results on the stimulatory effect of inulin on $\mathrm{Ca}$ and $\mathrm{Mg}$ absorption in the elderly.

\section{Abbreviations}

Ca: calcium; Mg: Magnesium; ICP/MS: Inductively coupled plasma/mass spectrometry, OS: oligosaccharides; SCFA: Short-chain fatty acids;

\section{Acknowledgements}

The authors are grateful to ORAFTI (Tienen, Belgium) for providing the inulin for this study. The authors thank Séverine Thien, Lydia Jaffrelo, Claudine Lab and Pierre Lamby for their technical assistance.

\section{References}

I. Gibson GR, Beatty ER, Wang X, Cummings JH: Selective stimulation of bifidobacteria in the human colon by oligofructose and inulin. Gastroenterology 1995, 108:975-982.

2. Jackson KG, Taylor GR, Clohessy AM, Williams CM: The effect of the daily intake of inulin on fasting lipid, insulin and glucose concentrations in middle-aged men and women. $\mathrm{Br} J \mathrm{Nutr}$ 1999, 82:23-30.

3. Kaur N, Gupta AK: Applications of inulin and oligofructose in health and nutrition. J Biosci 2002, 27:703-7I4.

4. Delzenne N, Aertssens J, Verplaetse H, Roccaro M, Roberfroid M: Effect of fermentable fructo-oligosaccharides on mineral, nitrogen and energy digestive balance in the rat. Life Sci 1995, 57:1579-1587.

5. Ohta A, Ohtsuki M, Baba S, Adachi T, Sakata T, Sakaguchi E: Calcium and magnesium absorption from the colon and rectum are increased in rats fed fructooligosaccharides. J Nutr 1995, I 25:24 I 7-2424.

6. Younes $\mathrm{H}$, Demigne $\mathrm{C}$, Remesy $\mathrm{C}$ : Acidic fermentation in the caecum increases absorption of calcium and magnesium in the large intestine of the rat. $\mathrm{Br}$ J Nutr 1996, 75:30I-3।4.

7. Levrat MA, Remesy C, Demigne C: High propionic acid fermentations and mineral accumulation in the cecum of rats adapted to different levels of inulin. J Nutr 1991, I 2 I: |730- I 737.

8. Lutz T, Scharrer E: Effect of short-chain fatty acids on calcium absorption by the rat colon. Exp Physiol I991, 76:615-618.

9. Trinidad TP, Wolever TM, Thompson LU: Effects of calcium concentration, acetate, and propionate on calcium absorption in the human distal colon. Nutrition 1999, I 5:529-533.

10. Topping DL, Clifton PM: Short-chain fatty acids and human colonic function: roles of resistant starch and nonstarch polysaccharides. Physiol Rev 2001, 81: I03 I-1064.

II. Remesy C, Levrat MA, Gamet L, Demigne C: Cecal fermentations in rats fed oligosaccharides (inulin) are modulated by dietary calcium level. Am J Physiol 1993, 264:G855-62.

12. Coudray C, Tressol JC, Gueux E, Rayssiguier Y: Effects of inulintype fructans of different chain length and type of branching on intestinal absorption and balance of calcium and magnesium in rats. Eur J Nutr 2003, 42:91-98.

13. Coudray C, Demigne C, Rayssiguier Y: Effects of dietary fibers on magnesium absorption in animals and humans. J Nutr 2003, 133:1-4.

14. Demigne C, Remesy C, Rayssiguier Y: Effect of fermentable carbohydrates on volatile fatty acids, ammonia and mineral absorption in the rat caecum. Reprod Nutr Dev 1980, 20:1351-1359.

15. De Bievre P, Taylor PDP: Table of isotopic composition of the elements. International Journal of Mass Spectrometry Ion Process 123 1993, 123:149-166.

16. Coudray C, Pepin D, Tressol JC, Bellanger J, Rayssiguier Y: Study of magnesium bioavailability using stable isotopes and the inductively-coupled plasma mass spectrometry technique in the rat: single and double labelling approaches. Br J Nutr 1997, 77:957-970.

17. Coudray C, Bellanger J, Castiglia-Delavaud C, Remesy C, Vermorel M, Rayssignuier Y: Effect of soluble or partly soluble dietary fibres supplementation on absorption and balance of calcium, magnesium, iron and zinc in healthy young men. Eur J Clin Nutr 1997, 5 |:375-380.

18. Lopez HW, Coudray C, Levrat-Verny MA, Feillet-Coudray C, Demigne C, Remesy C: Fructooligosaccharides enhance mineral apparent absorption and counteract the deleterious effects of phytic acid on mineral homeostasis in rats. J Nutr Biochem 2000, I I:500-508.

19. Younes H, Coudray C, Bellanger J, Demigne C, Rayssiguier Y, Remesy $C$ : Effects of two fermentable carbohydrates (inulin and resistant starch) and their combination on calcium and magnesium balance in rats. $\mathrm{Br} J$ Nutr 2001, 86:479-485.

20. Ohta A, Ohtsuki M, Baba S, Hirayama M, Adachi T: Comparison of the nutritional effects of fructo-oligosaccharides of different sugar chain length in rats. Nutr Res 1998, I 8:109-120.

21. Scholz-Ahrens KE, Schaafsma G, van den Heuvel EG, Schrezenmeir J: Effects of prebiotics on mineral metabolism. Am J Clin Nutr 200I, 73:459S-464S.

22. Cashman K: Prebiotics and calcium bioavailability. Curr Issues Intest Microbiol 2003, 4:21-32. 
23. Kayne LH, Lee DB: Intestinal magnesium absorption. Miner Electrolyte Metab 1993, 19:210-217.

24. Schaafsma G: Bioavailability of calcium and magnesium. Eur J Clin Nutr 1997, 5 I Suppl I:SI 3-6.

25. Armbrecht $\mathrm{HJ}$ : Effect of age on calcium and phosphate absorption. Role of I,25-dihydroxyvitamin D. Miner Electrolyte Metab 1990, 16:159-166.

26. Chan EL, Lau E, Shek CC, MacDonald D, Woo J, Leung PC, Swaminathan R: Age-related changes in bone density, serum parathyroid hormone, calcium absorption and other indices of bone metabolism in Chinese women. Clin Endocrinol (Oxf) 1992, 36:375-381.

27. Kinyamu HK, Gallagher JC, Prahl JM, DeLuca HF, Petranick KM, Lanspa SJ: Association between intestinal vitamin $D$ receptor, calcium absorption, and serum $I, 25$ dihydroxyvitamin $D$ in normal young and elderly women. J Bone Miner Res 1997, 1 2:922-928.

28. Weaver CM: Age related calcium requirements due to changes in absorption and utilization. J Nutr 1994, 1 24: |418S-1425S.

29. Chonan $\mathrm{O}$, Watanuki M: The effect of 6 '-galactooligosaccharides on bone mineralization of rats adapted to different levels of dietary calcium. Int J Vitam Nutr Res 1996, 66:244-249.

30. Coudray C, Feillet-Coudray C, Tressol JC, Gueux E, Thien S, Jaffrelo L, Mazur A, Rayssiguier Y: Stimulatory effect of inulin on intestinal absorption of calcium and magnesium in rats is modulated by dietary calcium intakesShort- and long-term balance studies. Eur J Nutr 2004.

31. Ohta A, Motohashi Y, Ohtsuki M, Hirayama M, Adachi T, Sakuma K. Dietary fructooligosaccharides change the concentration of calbindin-D9k differently in the mucosa of the small and large intestine of rats. J Nutr 1998, I 28:934-939.

32. Takasaki M, Inaba H, Ohta A, Motohashi Y, Sakai K, Morris H, Sakuma $\mathrm{K}$ : Dietary short-chain fructooligosaccharides increase calbindin-D9k levels only in the large intestine in rats independent of dietary calcium deficiency or serum 1,25 dihydroxy vitamin D levels. Int / Vitam Nutr Res 2000, 70:206-2 I3.

33. Durlach J, Bac P, Durlach V, Rayssiguier Y, Bara M, Guiet-Bara A: Magnesium status and ageing: an update. Magnes Res 1998, I I:25-42.

34. Coudray C, Gaumet N, Bellanger J, Coxam V, Barlet JP, Rayssiguier Y: Influence of age and hormonal treatment on intestinal absorption of magnesium in ovariectomised rats. Magnes Res 1999, 12:109-114.

35. Vaquero MP: Magnesium and trace elements in the elderly: intake, status and recommendations. J Nutr Health Aging 2002, 6:147-153.

36. Ferment $O$, Touitou $Y$ : Magnesium: metabolism and hormonal regulation in different species. Comp Biochem Physiol A 1985, 82:753-758.

37. Hardwick LL, Jones MR, Brautbar N, Lee DB: Site and mechanism of intestinal magnesium absorption. Miner Electrolyte Metab 1990, 16:174-180.
Publish with Bio Med Central and every scientist can read your work free of charge

"BioMed Central will be the most significant development for disseminating the results of biomedical research in our lifetime. "

Sir Paul Nurse, Cancer Research UK

Your research papers will be:

- available free of charge to the entire biomedical community

- peer reviewed and published immediately upon acceptance

- cited in PubMed and archived on PubMed Central

- yours - you keep the copyright
BioMedcentral 